Original Paper http://ajol.info/index.php/ijbcs http://indexmedicus.afro.who.int

\title{
Vegetarian diet in Guenon and Mangabey monkeys of Moukalaba-Doudou National Park, Gabon: Similarities and Differences
}

\author{
Lilian Brice MANGAMA-KOUMBA ${ }^{1,2^{*}}$, Ghislain Wilfried EBANG ELLA ${ }^{1,2}$, \\ Etienne François AKOMO-OKOUE ${ }^{2}$, Fred Loique MINDONGA NGUELET ${ }^{1,2}$, \\ Bertrand M'BATCHI ${ }^{1}$ and Jacques François MAVOUNGOU ${ }^{2}$ \\ ${ }^{1}$ Université des Sciences et Techniques de Masuku (USTM), BP: 901, Gabon. \\ ${ }^{2}$ Institut de Recherche en Ecologie Tropicale (IRET), BP : 13354, Gabon. \\ *Corresponding author; E-mail: mangamalilian@yahoo.fr; Tel : +241065991 77/07 154745
}

\section{ACKNOWLEDGMENTS}

This study was financed in part by a Grant-in-Aid for the Doctor Course Program of Universite des Sciences et Techniques de Masuku (to LBM-K), Grants-in-Aid for Scientific Research by the Ministry of Education, Culture, Sports, Science and Technology, Japan (No. 162550080, No. 19107007, No. 24255010 to J. YAMAGIWA), and SATREPS (Science and Technology Research Partnership for Sustainable Development) by JST/JICA, Japan.

\begin{abstract}
To order to know any differences and similarities between Mangabeys and Guenons study of their vegetarian diet was conducted for 10 months between 2013 and 2014 in Moukalaba-Doudou National Park, Gabon. By using the direct observation method, we identified 84 plant species integral to the vegetarian diet of these two groups of monkeys. Thus, we have recorded similarities and differences. Guenons (69 species) consume the same plant species as the Mangabeys (49 species; V $=1594$ p-value $=0.1796$ ). They are considered frugivores at large because they consume an average of $84.77 \%$ fruit for guenons and $63.37 \%$ for the mangabeys, with a difference in the consummation of seeds $18.93 \%$ and $3.31 \%$ respectively. These results suggest that Mangabey have a seed-eating regime while the guenons tend to consume even when they are unavailable fruits. Our analyzes also showed that these two groups have preference different family of the species that they consume. This is due to the nature of the fruit produced by each family. Furthermore the mangabey (chi-squared $=5.6989, \mathrm{df}=5, \mathrm{p}$-value $=0.3366)$ interested in several of plants while monkeys (chisquared $=15.817, \mathrm{df}=5, \mathrm{p}$-value $=0.007387$ ) remain more attached to fruit consumption.
\end{abstract}

(C) 2016 International Formulae Group. All rights reserved.

Keywords: Mangabeys, Guenons, diet, Moukalaba-Doudou, difference and similarity.

\section{INTRODUCTION}

Cercopithecines monkey are considerate as the large group of diurnal primates of African and Asian tropical forest (Grubb et al., 2003; Marini et al., 2012).
Cercopithecines include 12 genera divided into two tribes, Cercopithecini (Guenons) and Papionini (baboons, mangabeys and macaques; Smith and Junger, 1997). Many genera of Cercopithecines occupy habitats of 
African forest, where they form exceptionally diverse communities in tropical forests including up to four different species with colobus monkeys and great apes (gorillas, chimpanzees and bonobos).

In Gabon, African country, there are 13 national parks including the MoukalabaDoudou National Park which is the third largest. This park is known for his diverse habitats and his characteristics in primatology. Today it is considered as a sanctuary of western lowland gorillas, with an abundance and high density of apes (Takenoshita and Yamagiwa, 2008; Nakashima et al., 2013b). Also, there are two main groups of Cercopithecines monkeys (Mangabeys and Guenons) and a lack of colobines monkey which generally dominated in the African rainforest (Chapman et al., 1999; Matsuda et al., 2013a). Mangabeys and Guenons form permanent polyspecific associations and share the same habitats. They have common behavior and their diet is varied: fruits, flowers, buds, plant stems, leaves, nuts, roots, bulbs, corms, insects and bird eggs (NRC, 2003). A study of Chapman et al (2002) and analysis of others author showed that many groups of cercopithecines frequently eat diets which, though very similar in gross content (percentage of fruit, leaves, insect matter, and other materials), differ in the specific plants consume. Also, monkey's population of the same species in different forests ate diets that tended to be more similar to sympatric groups of other species than to conspecifics in other forests.

Morphological and behavioral
differences, which presumably reflect
different positional behaviors, were found
within both Guenons and Mangabeys groups
(Nakatsukasa, 1994), and in areas where
living sympatricaly Colobus, Guenons and
Mangabeys, diets of each group have been
widely discussed (Chapman et al., 2002;
Buzzard, 2006; Harris and Chapman, 2007).
However, there are few data on the difference
of diets between these two groups in a region
where they are sympatric and where there is a
lack of Colobine monkeys.

This study is dedicated to the analysis of vegetarian diet of Mangabeys and Guenons monkey of Moukalaba-Doudou National Park, Gabon. The objective is to identify, quantify and compare their diets and in order to bring the differences and similarities.

\section{MATERIALS AND METHODS}

\section{Study site}

The Moukalaba-Doudou National Park is located at south-western Gabon and covers an area of $\sim 5028 \mathrm{~km}^{2}$ (Figure 1). This park (S02 $\left.20^{\prime} 49.0^{\prime \prime} ; \quad \mathrm{E} 010^{\circ} 34^{\prime} 19.0^{\prime \prime}\right)$ is located mainly in the province of Nyanga (Mounioko et al., 2015). The park faces the Atlantic Ocean on its south-western boundary. The Doudou mountain Range, up to $900 \mathrm{~m}$ in altitude, runs north to south. The Park contains a mosaic of vegetation: primary and secondary forest, mountain forest, marsh and savannah (Iwata and Ando, 2007). The study area covers approximately $500 \mathrm{~km}^{2}$ around the village of Doussala, which is located on the eastern side of the park. During 2004-2006, the annual rainfall fluctuated between 1582 $\mathrm{mm}$ and $1886 \mathrm{~mm}$ (Ando et al., 2008; Takenoshita et al., 2008), and the mean monthly minimum and maximum temperatures range from $21.3{ }^{\circ} \mathrm{C}$ to $24.1{ }^{\circ} \mathrm{C}$ and from $29.3{ }^{\circ} \mathrm{C}$ to $33.7{ }^{\circ} \mathrm{C}$, respectively (Takenoshita et al., 2008). They are two distinct seasons a rainy season from October to April, and a dry season from May to September. During the 3 months in the middle of the dry season, rainfall is very infrequent (Thibault et al., 2004). The high-altitude forest $(>450 \mathrm{~m})$ in the Doudou mountain is believe to be one the Pleistocene refuges, and may harbor some endemic plant species (Sossef et al., 2004). Fisher (2004) conducted a floral and faunal inventory survey of the study area.

\section{Data collection and analysis}

Two species of mangabeys the Redcapped mangabey Cercocebus torquatus and the Grey-cheeked mangabey Lophocebus albigena, and four species of guenons, the mustached Cercopithecus cephus, Putty-nosed Cercopithecus nictitans, the crowned 
Cercopithecus pogonias, the Northern talapoin Miopithecus ogoouensis (Wilson and Reeder, 2005) was chosen as target species.

Diet records were compiled have been made for each species from direct observations on unmarked individual at Northeastern part of Moukalaba-Doudou National Park. Survey was done randomly, and observers walked in all major habitats in the study area. The observations were made in four zones which composed our study area. The zones were walked in sequences so that all zones were sampled by month, excepted the month of December 2013 and January 2014 which had been disturbed by the mission programs. Whenever vocalization of mangabeys or guenons was understood, we got closer of the group and we marked their activities. If monkeys were feeding, we recorded the plant species and plant item (i.e., fruit, leaf, seed, bud...) which they consumed. We recorded also, all others foods that were not plants. Each fruiting plants was considered a subject, and only one feeding observation was counted per frugivore species, irrespective of the number of individual feeding. Furthermore, a fruit species was designated as a diet item if a frugivore was been observed to ingest the fruit, or to regurgitate or defecate a seed. Areas of feedings monkeys were regularly scanned by the observer to identify fruit consumed by mangabeys and guenons. Feeding observation of Mangabeys and Guenons were recorded from July 2013 and June 2014 except the months of December 2013 and January 2014.

The data collected were analyzed by $\mathrm{R}$ commander. The means of observations made were calculated. The statistical test $\mathrm{H}$ of Kruskal-Wallis was used for simultaneous comparison of the means and Wicoxon test for analysis of means series paired. The differences in the consumption of parts of plants (fruits, leaves, seeds, bark, and dead wood) have been shown in boxplots. The differences in tree and liana families consumed by the two main groups (Guenons and Mangabeys) were established.

\section{RESULTS}

During 10 months, a total of 553 combined observations of Mangabeys and Guenons have been made of which the main activity was supply feeding (251 observations from Mangabeys and 302 from Guenons). Table 1 shows the list of plant species eaten by Guenons and Mangabeys. They are 84 plant species belonging to 33 different families which compose diet of Mangabeys and Guenons. Whether around 45 species inventoried for Mangabeys supply and 69 species for Guenons $(\mathrm{V}=1594$, p-value $=$ 0.1796). These results suggest that there are similarities and differences in the frugivorous diet of both groups.

The observations of diets of Mangabeys and Guenons have shown that their plant-term consumption is limited only to 6 mainly plant parts: fruits, flowers, leaves, seeds, bark and dead wood. The results show that the Guenons have a relatively small spectrum fruits while that of Mangabeys is wide. Figure 2 shows that the percentages of fruits of Guenons $(84.77 \%)$ are greater than that of Mangabeys $(63.37 \%)$. The consumption of the seeds is higher into Mangabeys compared to Guenons when in regards sheets, the difference is not significant. We note also a lack of consumption of flowers and dead wood that are widely well below those observed at the Mangabeys.

Data analysis on the top 10 of the various families of plants consumed by monkey's shows that the families most consumed by Guenons are different from those consumed by the Mangabeys. In the top 10 families consumed by Guenons, we have Moraceae, Myristicaceae and Vitacae. Mangabeys as to them consume in the major part of their time the species of Mimosaceae, Ceasalpiniaceae and Myristicaceae.

In the list of plant species consumed by two major groups combined, it appears that the Guenons eat more plants than Mangabeys. Figures $4 \mathrm{a}$ and $4 \mathrm{~b}$ show us that Guenons consume fruits of several plant species while Mangabeys consume an average amount of 
different of plants that they consume. The fruit average consumed in the Guenons is much higher than the averages of seeds, leaves, flowers, and dead wood. To the Mangabeys there is not difference. The Kruskal-Wallis test $\mathrm{H}$ is significant for Guenons (chi-squared $=15,817$, $\mathrm{df}=5$, $\mathrm{p}$ value $=0.007387$ ) and not significant for
Mangabeys (chi-squared $=5.6989, \mathrm{df}=5, \mathrm{p}$ value $=0.3366$ ). More than all the species eaten by monkeys only the fruits are preferred while Mangabeys not only consume the fruits but also, the leaves, seeds, flowers, bark and dead wood. This result suggests that the Mangabeys have a broad spectrum of plant species for consumption.

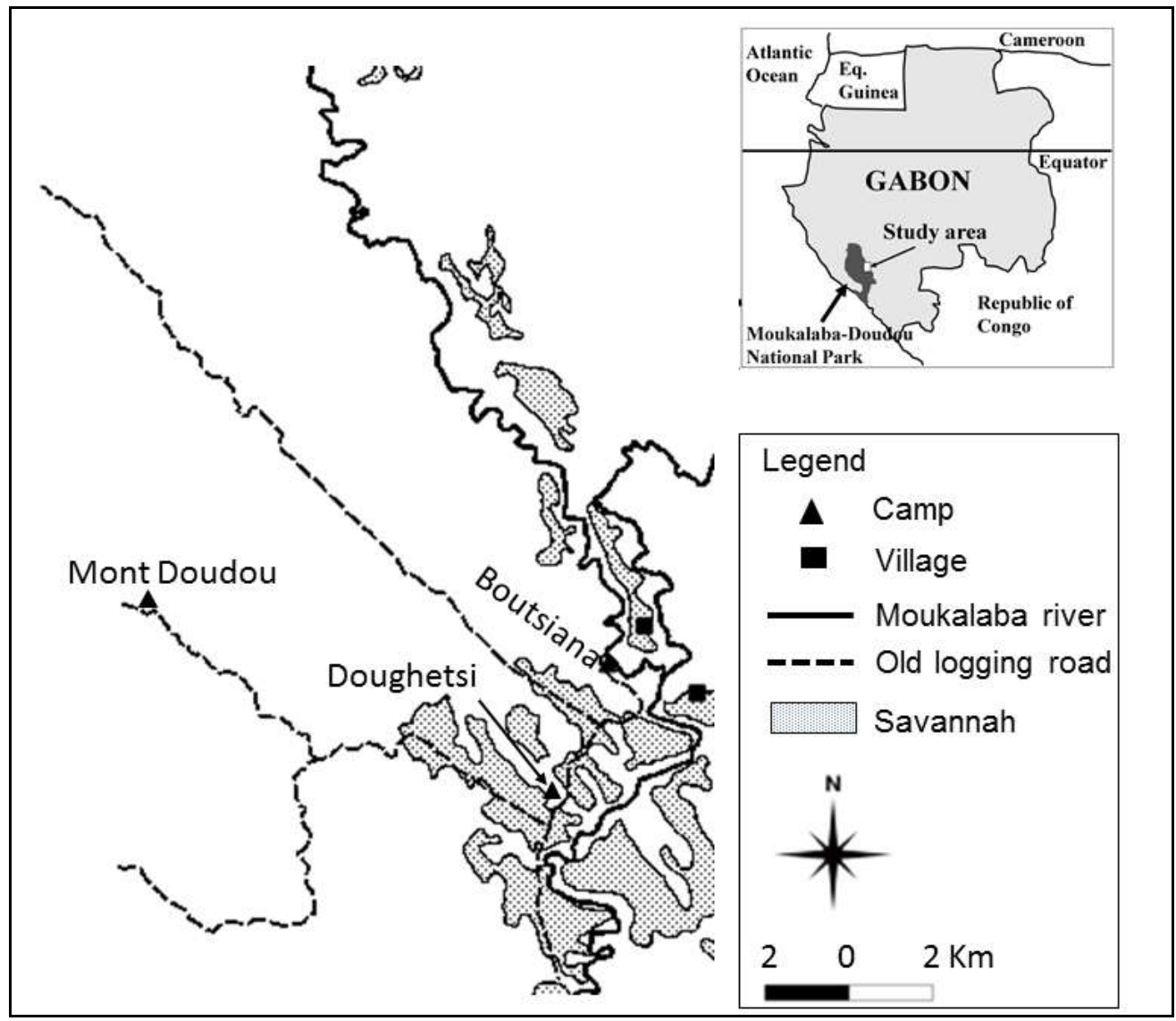

Figure 1: Localization of study site of Northen part of Moukalaba-Doudou National Park.

Tableau 1: List of plants eaten by Guenons and Mangabeys.

\begin{tabular}{lcc}
\hline Plant species & Guenons & Mangabeys \\
\hline Aframomum leptolepis & $\mathrm{x}$ & \\
Afrostyrax lepidophyllus & $\mathrm{x}$ & $\mathrm{xx}$ \\
Afzelia bella & & $\mathrm{xxx}$ \\
Anthonotha sp & & $\mathrm{xx}$ \\
Anthostema aubryanum & $\mathrm{xx}$ & \\
Aucoumea klaineana & $\mathrm{x}$ & $\mathrm{xx}$ \\
Baillonella toxisperma & & \\
Berlinia bracteosa & & \\
\hline
\end{tabular}




\begin{tabular}{|c|c|c|}
\hline Caloncoba welwitschii & $\mathrm{xxx}$ & \\
\hline Calpocalyx heitzii & $\mathrm{x}$ & $\mathrm{xx}$ \\
\hline Cassia mannii & $\mathrm{xx}$ & $\mathrm{xx}$ \\
\hline Ceiba pentandra & $\mathrm{x}$ & $\mathrm{xX}$ \\
\hline Celtis tessmanii & $\mathrm{x}$ & $\mathrm{x}$ \\
\hline Cissus dinklagei & $\mathrm{xxx}$ & $\mathrm{xx}$ \\
\hline Cola sp & $\mathrm{xx}$ & \\
\hline Cola sp & $\mathrm{x}$ & \\
\hline Cola sp1 & $\mathrm{x}$ & \\
\hline Coula edulis & & $\mathrm{x}$ \\
\hline Cylicodiscus gabunensis & $\mathrm{x}$ & $\mathrm{xxx}$ \\
\hline Dacryodes butnerii & $\mathrm{xx}$ & $\mathrm{xx}$ \\
\hline Dacryodes buttneri (Pachylobus b.) & $\mathrm{x}$ & $\mathrm{x}$ \\
\hline Desbordesia $s p$ & $\mathrm{x}$ & $\mathrm{xX}$ \\
\hline Dialum $s p$ & $\mathrm{xx}$ & $\mathrm{xx}$ \\
\hline dibindi & $\mathrm{x}$ & \\
\hline Diogoa zenkeri & $\mathrm{xx}$ & \\
\hline Diospyros mannii & $\mathrm{xx}$ & $\mathrm{x}$ \\
\hline Diospyros $s p$ & $\mathrm{x}$ & $\mathrm{x}$ \\
\hline Diospyros sp 1 & $\mathrm{x}$ & $\mathrm{x}$ \\
\hline Disthemonentus sp & $\mathrm{XX}$ & $\mathrm{x}$ \\
\hline Duboscia macrocarpa & $\mathrm{xx}$ & $\mathrm{xxx}$ \\
\hline Ficus sp & $\mathrm{xxx}$ & \\
\hline Gambeya africana & $\mathrm{xx}$ & $\mathrm{xx}$ \\
\hline Garcinia cola & $\mathrm{x}$ & \\
\hline Guibourtia tessmanii & $\mathrm{x}$ & $\mathrm{x}$ \\
\hline Harungana madagascariensis & & $\mathrm{x}$ \\
\hline Indetermined 2 & & $\mathrm{XX}$ \\
\hline Indetermined 3(Ilalaba) & $\mathrm{xx}$ & \\
\hline Indetermined 4(muvayu) & & $\mathrm{x}$ \\
\hline Indetermined 5 & & $\mathrm{x}$ \\
\hline Indetermined 6 & & $\mathrm{x}$ \\
\hline Indetermined 7 & $\mathrm{x}$ & \\
\hline Irvingia gabonensis & $\mathrm{x}$ & $\mathrm{xx}$ \\
\hline Irvingia grandifolia & $\mathrm{x}$ & $\mathrm{x}$ \\
\hline Klainedoxa gabonensis & $\mathrm{xx}$ & $\mathrm{xx}$ \\
\hline Landolphia mannii & $\mathrm{x}$ & \\
\hline Lannea welwitchii & $\mathrm{xx}$ & $\mathrm{x}$ \\
\hline Macaranga spinosa & $\mathrm{XX}$ & $\mathrm{x}$ \\
\hline Mammea africana & $\mathrm{x}$ & \\
\hline Meiocarpidium lepidotum & $\mathrm{x}$ & $\mathrm{xx}$ \\
\hline Milicia excelsa & $\mathrm{x}$ & $\mathrm{x}$ \\
\hline Musanga cecropioides & $\mathrm{xxx}$ & \\
\hline Myrianthus arboreus & $\mathrm{xx}$ & $\mathrm{x}$ \\
\hline Nauclea diderichii & $\mathrm{x}$ & $\mathrm{x}$ \\
\hline Octobotolis sp (grand fudi) & $\mathrm{x}$ & \\
\hline Pachylobus ferruginea? & $\mathrm{x}$ & $\mathrm{x}$ \\
\hline Panda oleosa & $\mathrm{xx}$ & \\
\hline
\end{tabular}




\begin{tabular}{|c|c|c|}
\hline Parinari sp & $\mathrm{xx}$ & $\mathrm{x}$ \\
\hline Parkia bicolor & & $\mathrm{x}$ \\
\hline Pentaclethra macrophylla & $\mathrm{xx}$ & $\mathrm{xxx}$ \\
\hline Piptadeniastrum africanum & $\mathrm{xx}$ & $x x$ \\
\hline Plagiostyles africana & $\mathrm{xx}$ & \\
\hline Polyalthia suaveolens & $\mathrm{x}$ & $\mathrm{x}$ \\
\hline Pseudospondias longifolia & $\mathrm{xxx}$ & $\mathrm{xx}$ \\
\hline Pterocarpus soyauxii & $\mathrm{xx}$ & $\mathrm{xx}$ \\
\hline Pycnanthus angolensis & $\mathrm{xxx}$ & $\mathrm{xxx}$ \\
\hline Sacoglottis gabonensis & $\mathrm{x}$ & $\mathrm{XX}$ \\
\hline Salacia sp & $\mathrm{x}$ & \\
\hline Santiria trimera & $\mathrm{xx}$ & $\mathrm{x}$ \\
\hline Scyphocephalium ochoncoa & & $\mathrm{x}$ \\
\hline Staudtia gabonensis & $\mathrm{xxx}$ & $\mathrm{xxx}$ \\
\hline Strychnos sp.? & $\mathrm{x}$ & \\
\hline Swartzia fistuloides & & $\mathrm{xx}$ \\
\hline Synsepalum dulcificum & $\mathrm{xx}$ & $\mathrm{x}$ \\
\hline Tetrapleura tetrapleura & $\mathrm{x}$ & $\mathrm{xxx}$ \\
\hline Tieghmella africana & $\mathrm{x}$ & $\mathrm{x}$ \\
\hline Trichilia prieureana & $\mathrm{xx}$ & $\mathrm{xx}$ \\
\hline Tricoscypha sp & $\mathrm{xx}$ & $\mathrm{x}$ \\
\hline Uapaca guineensis & $\mathrm{x}$ & $\mathrm{xx}$ \\
\hline Vitex $s p$ & & $\mathrm{x}$ \\
\hline Xylopia aethiopica & $\mathrm{xx}$ & $\mathrm{x}$ \\
\hline Xylopia guintasii & $\mathrm{xx}$ & $\mathrm{xxx}$ \\
\hline Xylopia hypolampra & & $\mathrm{x}$ \\
\hline Xylopia staudtii & $\mathrm{x}$ & $\mathrm{x}$ \\
\hline Indetermined1(mousoni cocu) & $\mathrm{x}$ & $\mathrm{x}$ \\
\hline
\end{tabular}

$\mathrm{x}$ represent diet preference; $\mathrm{x}$ :low preference; $\mathrm{xx}$ : average preference et $\mathrm{xxx}:$ high preference.

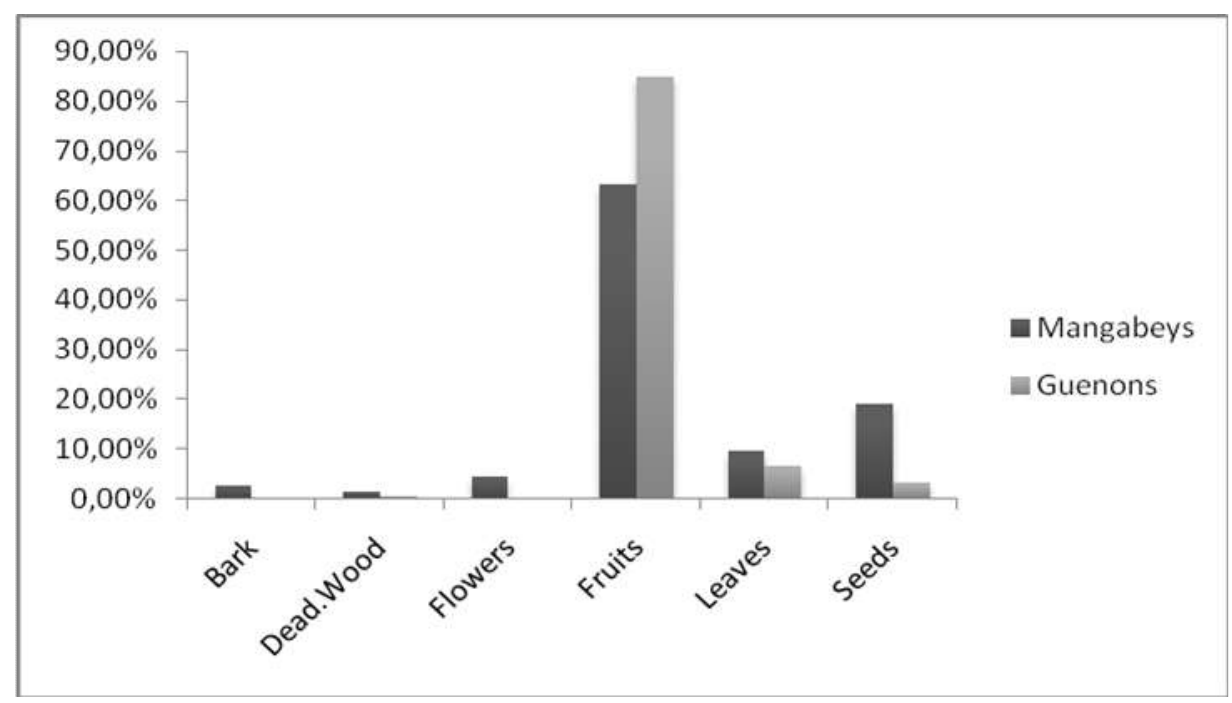

Figure 2: Percentage of consumption of plant parts by Guenons and Mangabeys. 


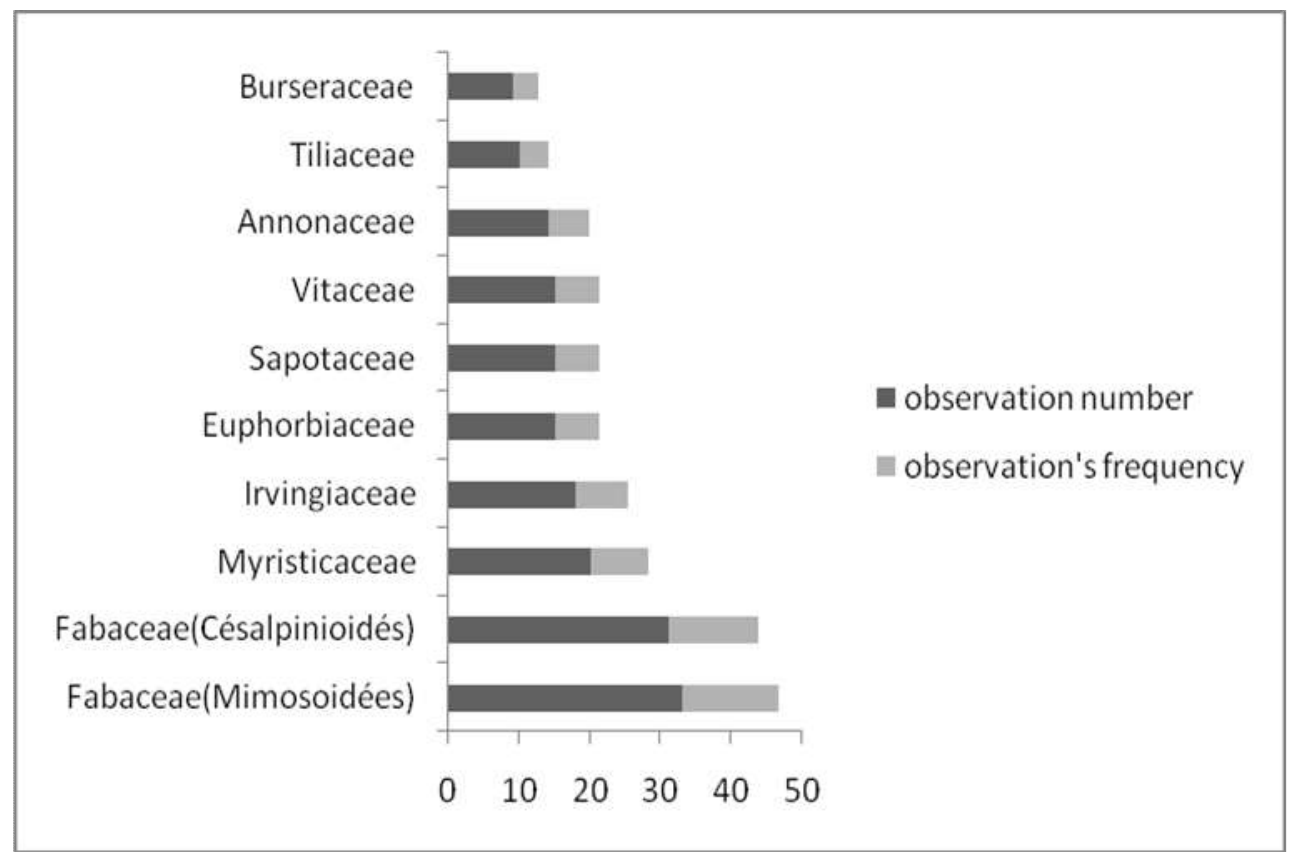

A)

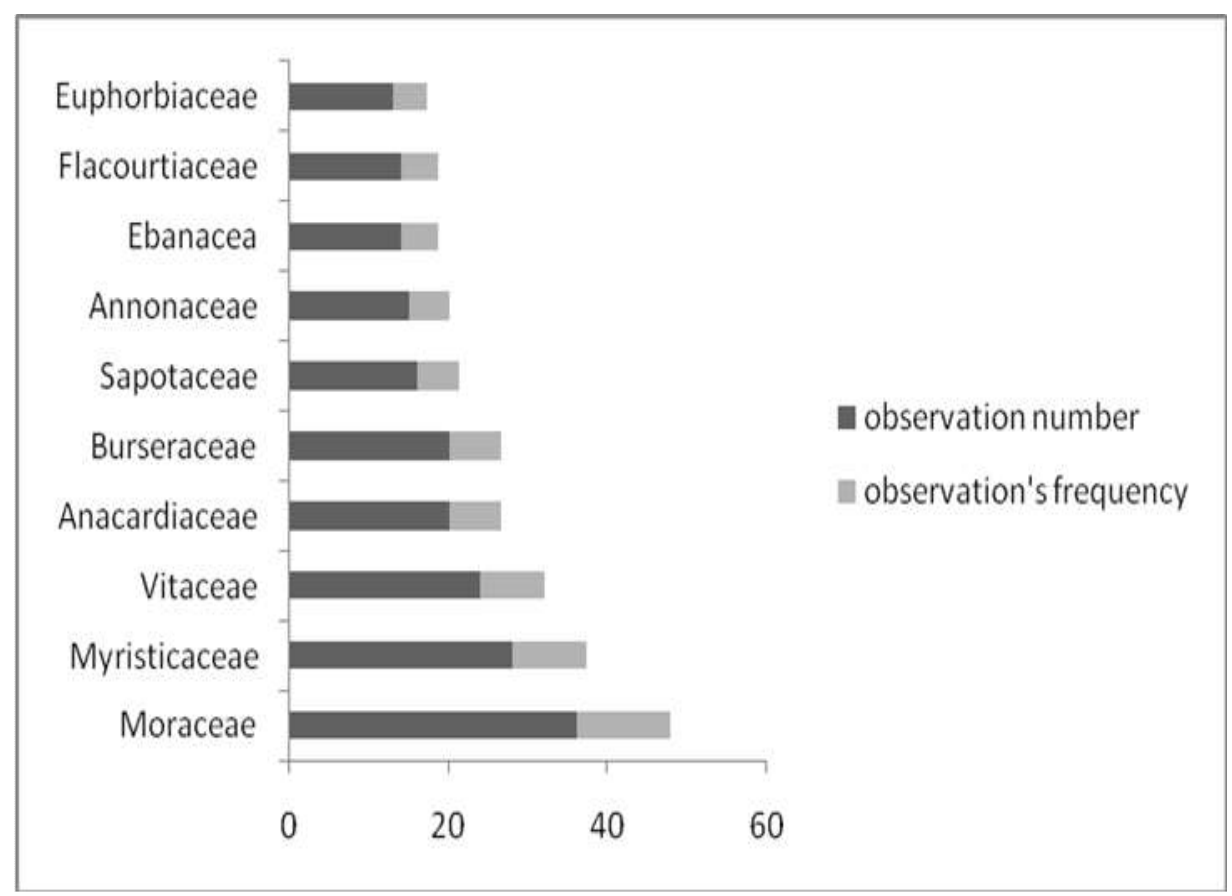

B)

Figure 3: Top 10 families consumed by both groups. A) Mangabeys and B) Guenons. 


\section{frequency's observation of guenons}

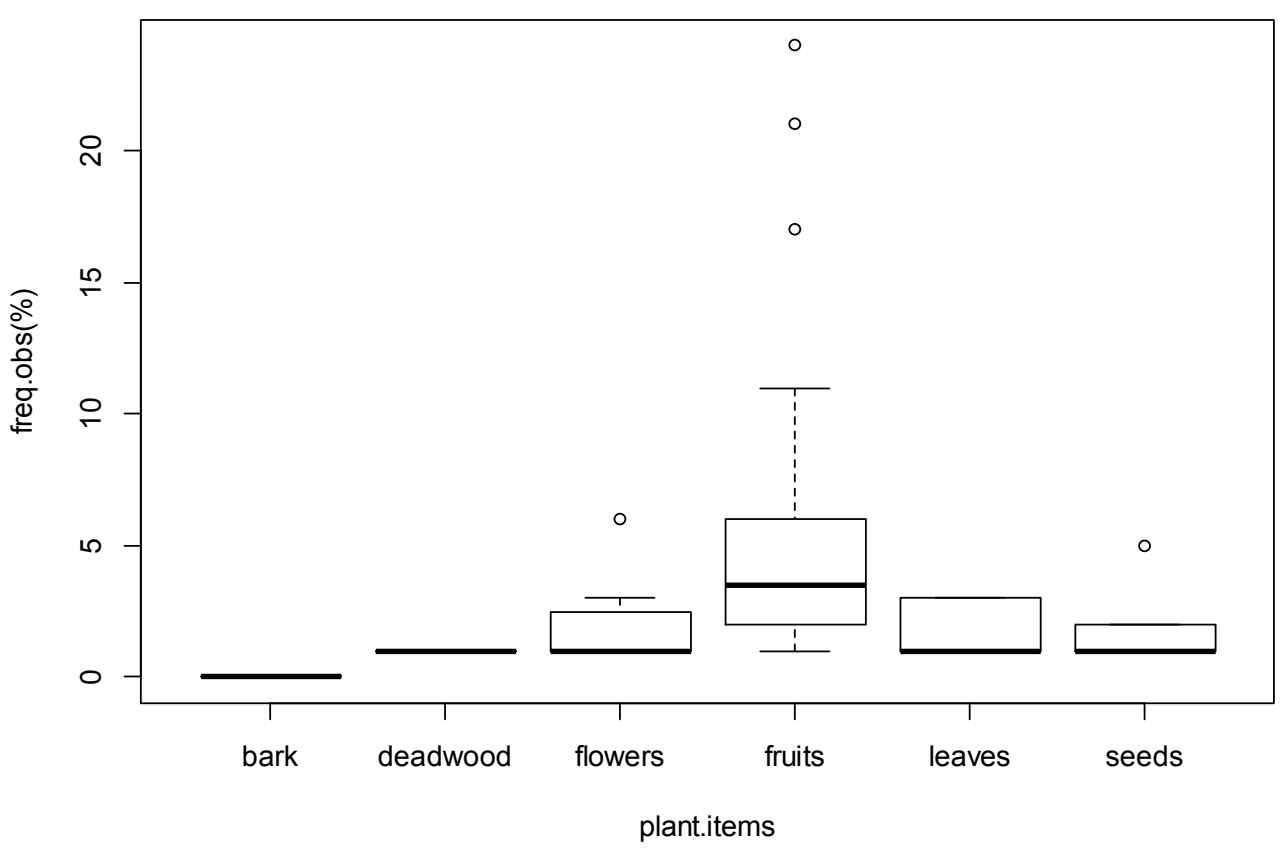

A)

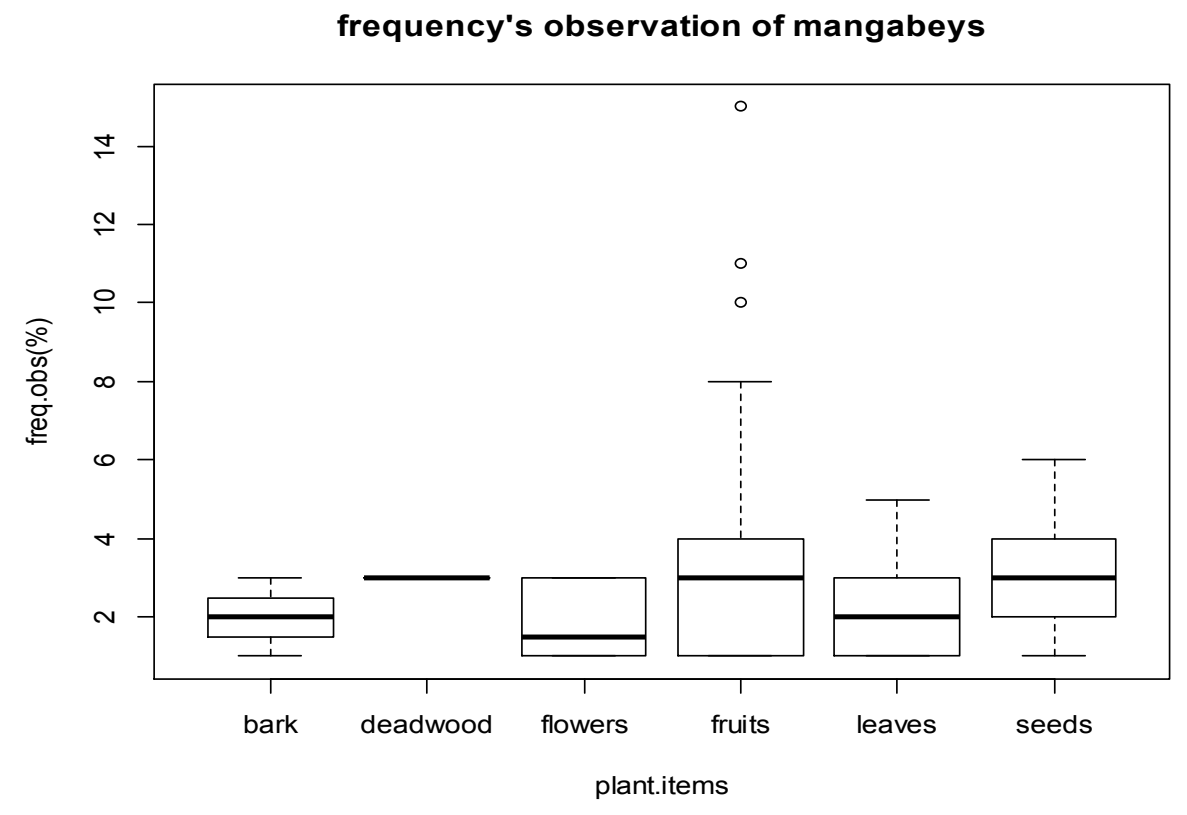

B)

Figure 4: Observation frequency in the plant parts supply. A) Guenons B) Mangabeys. 


\section{DISCUSSION}

The vegetarian diet of Mangabeys and Guenons of Moukalaba-Doudou collected during a 10 month period has shown that in their diet small monkeys together consume 84 different plant species. 69 species were identified in the diet of Guenons while mangabeys we identified 44 species. The difference was not significant. They consume the same plant species in the majority of cases. Three fruit species were preferred by both monkeys group (Pycnanthus angolensis, Staudtia gabonensis and Cissus dinklagei). Previous studies of fruit-eating primates have often reported between 75 and 100 different species in their dietary (Gautier-Hion, 1988; Ham, 1994; Tutin et al., 1997; Anderson et al., 2005). Our results show high percentages of fruit $84.77 \%$ and $63.37 \%$ respectively in Guenons and Mangabeys. However, consumption of seeds is representative in Mangabeys than in Guenons. To Dja National Park in Cameroon, guenons consume $78 \%$ of fruits and seeds $4 \%$ while mangabeys ate $47 \%$ fruit and 31\% seeds (Poulsen et al., 2000). Our results show that it would be a difference in the consumption of seeds between mangabeys and Guenons (18.93\% and 3.31\% respectively). In other areas, where Guenons, Mangabeys and Colobines the results show that Colobines consume more seeds than the other two groups (Sun et al., 2007; Maisels et al., 1994) and are considered as predator of seeds. In Moukalaba, granivorous is observable among Mangabeys. Indeed, during periods of fruit scarcity, Mangabey consumes a wide variety of seeds while Guenons tend to look for fruit available (Poulsen et al, 2000; Anderson 2005). The dentition of Mangabeys is an adaptation in granivorious diet may be explaining this phenomenon (Kinzeyan Norconk, 1990, 1993; Lambert et al, 2004).

Our analysis allowed us to show that the Mangabeys and Guenons eat different plant families. The Mangabeys consume mostly species of family of Ceasalpiniaceae, Mimosaceae and Myristicaceae while Guenons consume more species from families Moraceae, Myristicaceae and Vitaceae. These results are explained by the fact that the species of the families Mimosaceae and Caesalpiniaceae produce for most fruits whose seeds are consumed by Mangabeys whereas Guenons their dependence on the consumption of fruit is confirmed by the preference of Moraceae (Ficus sp et Musanga cecropioides) which produce fruit available for several months of the year (Gautier-Hion, 1984; Takenoshita et al., 2008). At Makokou, data on the diets of Guenons (Cercopithecus cephus, Cercopithecus nictitans and Cercopithecus pogonias) showed that Cissus dinklagei (Vitaceae) is an essential element in their diet of frugivorous (Gautier-Hion, 1980). Our results confirm that this food is preferred by Guenons. The preference of Myristicaceae by the two groups is due to the fact that during periods of fruit scarcity (dry season), they consume Pycnanthus angolensis and Staudtia gabonensis.

Finally, the analysis of vegetarian diet of Guenons and mangabeys has also shown that these two groups have different dietary strategy. Our results allowed to see that Mangabey consume several parts of plants unlike monkeys whose diet is more inclined towards fruit consumption. Indeed, consumption strategies could be explained by environmental factors, different habitats and behavior of species in each group. In the Mangabey group we have Cercocebus torquatus that are semi-terrestrial species and therefore have food diversity. Their strategy is different from the others because they can feed on all strata of the forest. Then Lophocebus albigena is known as strictly arboreal and therefore feeds on seeds, leaves etc. showed that Lophocebus albigena is omnivorous and consumes more parts of plants (Poulsen, 2001). Our results show that 
Mangabeys (Lophocebus albigena and Cercocebus torquatus) consume more plant parts in their diet and that monkeys have a tendency to consume fruits. We have obtained non-significant test from Mangabeys but significant test from Guenons.

\section{Conclusion}

In this study we think that, Guenons and Mangabeys consume a large variety of plant in Moukalaba-Doudou National Park. However, we have recorded many difference, Mangabeys consume different plant part whereas Guenons consume on majority fruits. This different diet may explain the lack of competition when those different groups form polyspecific associations.

\section{COMPETING INTERESTS}

The authors declare that they have no competing interests.

\section{AUTHORS' CONTRIBUTIONS}

LBM-K was the principal investigator and drafted the manuscript; GWEE and FLMN help in data collection and propositions; EFA-O performed research and Maps conception; BM and JFM participated in the study and manuscript writing. All authors read and approved the final manuscript.

\section{ACKNOWLEDGMENTS}

This study was conducted in cooperation among the Centre National de la Recherche Scientifique et Technologique (CENAREST), the Institut des Recherches en Ecologie Tropicale (IRET), Université des Sciences et Techniques de Masuku (USTM), Gabon, and Kyoto University, Japan. We thank the Agence Nationale des Parcs Nationaux (ANPN) of the Gabonese government for permission and support for our research project in Gabon. We are also greatly indebted to M. Makouloutou Patrice for her help and all the field assistants at
Moukalaba-Doudou National Park and the people in the villages of Doussala and Mboungou for their kind support and hospitality.

\section{REFERENCES}

Anderson DP, Nordheim EV, Moermond TC, Gone Bi ZB, Boesch C. 2005. Factors influencing tree phenology in Taï National Park, Côte d'Ivoire. Biotrop, 37(4): 631-640.

Ando C, Iwata Y, Yamagiwa J. 2008. Progress of habituation of western lowland gorillas and their reaction to observers in Moukalaba-Doudou National Park, Gabon. Afri. Stud. Mon., 39: 55-69.

Buzzard PJ. 2006. Ecological partitioning of Cercopithecus campbelli, C. petaurista, and $C$. diana in the Taï Forest. Int J. Primatol., 27(2): 529-558.

Chapman CA, Chapman LJ, Cords M, Gathua JM, Gautier-Hion A, Lambert JE, Rode K, Tutin CEG, White LJT. 2002. Variation in the diets of Cercopithecus species: differences within forests, among forests, and across species. In Glenn ME, Cords M (eds). The Guenons: Diversity and Adaptation in African Monkeys. Kluwer Academic/Plenum Publishers: New York; 325-350.

Fisher BL. 2004. Monts Doudou, Gabon: A Floral and Faunal Inventory: with Reference to Elevational Distribution. California Academy of Sciences: San Francisco.

Gautier-Hion A. 1980. Seasonal variation of diet related to species and sex in a community of Cercopithecus monkeys. $J$. An. Ecol., 49 : 237-269.

Gautier-Hion A. 1984. La dissemination des graines par les cercopithecides forestiers Africains. Terre. Vie., 39: 159-165.

Gautier-Hion A. 1988. The diet and dietary habitats of forest guenons. In Primate Radiation: Evolutionary Biology of the 
African Guenons, Gautier-Hion A, Bourliere F, Gautier JP, Kingdon J (eds). Cambridge University Press : Cambridge, UK. 257-283.

Gautier-Hion A, Brugière D. 2003. Significance of Riparian forest for the conservation of Central African Primates. Int. J. Primatol., 26: 515-523.

Grubb P, Butynski TM, Oates JF, Bearder SK, Disotell TR, Groves CP, Struhsaker TT. 2003. Assessment of the diversity of African primates. Int. J. Primatol., 24: 1301-1357.

Ham RM. 1994. Behaviour and ecology of the grey cheeked mangabeys (Cercocebus albigena) in the Lope Reserve, Gabon. Dissertation. University of Stirling, Stirling, UK.

Harris TR, Chapman CA. 2007. Variation in diet and ranging of black and white colobus monkeys in Kibale National Park, Uganda. Prim., 48: 208-221.

Iwata Y, Ando C. 2007. Nest and nest-site reuse by western lowland gorillas (Gorilla g.gorilla) in Moukalaba-Doudou National Park, Gabon. Prim., 48: 77-80.

Kinzey W, Norconk M. 1990. Hardness as a basis of fruit choice in two sympatric primates. Am. J. Physic. Anthrop., 81: 515.

Lambert JE. 1999. Seed handling in chimpanzees (Pan troglodytes) and redtail monkeys (Cercopithecus ascanius): implications for understanding hominoid and cercopithecine fruit-processing strategies and seed dispersal. Am. J. Physic. Anthrop., 109: 365-386.

Lambert JE, Chapman CA, Wrangham RW, Conklin-Brittain NL. 2004. Hardness of cercopithecine foods: implications for the critical function of enamel thickness in exploiting fallback foods. Am. J. Physic. Anthrop., 125: 363-368.

Maisels F, Gautier-Hion A, Gautier JP. 1994. Diets of two sympatric colobines in
Zaire : More evidence on seed-eating in foress on poor soils. Int. J. Prim., 15: 681-701.

Marini L, Bruun HH, Heikkinen RK, Helm A, Honnay O, Krauss J, Kühn I, Lindborg R, Pärtel M, Bommarco R. 2012. Traits related to species persistence and dispersal explain changes in plant communities subjected to habitat loss. Divers. Distrib., 18: 898-908.

Mounioko F, Dibakou ES, Zinga-Koumba CR, Mbang-Nguema OA, Acapovi-Yao G, Mutambwe S, Mavoungou JF. 2015. Rythme d'activité journalière de Glossina fuscipes fuscipes, vecteur majeur de la trypanosomiase humaine africaine dans le parc national de Moukalaba Doudou (Sud-Ouest Gabon). Int. J. Biol. Chem. Sci., 9(1): 419-429.

Nakashima Y, Iwata Y, Ando C, NzeNkogue $\mathrm{C}$, Inoue $\mathrm{E}$, AkomoOkoue $\mathrm{E}$, MbehangNguema P, DiopBineni T, NgokBanak L, Takenoshita Y, Ngomanda A, Yamagiwa J. 2013. Assessment of Landscape-Scale distribution of Sympatric Great Apes in African Rainforest Concurrent Use of Nest and camera-Trap surveys. Int. J. Prim., 99: 111.

Nakatsukasa M. 1994. Morphology of the humerus and femur in african mangabeys and guenons: functional adaptation and implications for the evolution of positional behavior. Afri. Stud. Mon., 21: $1-61$.

Poulsen RJ, Clark JC, Smith TB. 2001. Seasonal Variation in feeding Ecology of Grey-Cheeked Mangabey (Lophocebus albigena) in Cameroon. Int. J. Prim., 54: 91-105.

Poulsen RJ, Clark JC, Connord EF, Smith TB. 2002. Differential resource use by primates and hornbills: implications for seed dispersal. Ecol., 83: 228-240. 
Sosef MSM, Issembe Y, Bourobou HPB, Koopman WJM. 2004. Botanical diversity of the Pleistocene forest refugia Mounts Doudou. In Monts Doudou, Gabon: Floral and Faunal Inventory with Reference to Elevational Distribution, Fisher BL (ed). Calofolina Academy of Science: San Francisco, CA; 17-92.

Sun I, Chen Y, Hubbell S, Wright S, Noor N. 2007. Seed predation during general flowering events of varying magnitude in a Malaysian rain forest. J. Ecol., 95: 818827.

Takenoshita Y, Ando C, Yamagiwa J. 2008. Fruit phenology of the great ape habitat in the Moukalaba-Doudou National Park, Gabon. Afri. Stud. Mono., 39: 23-39.

Takenoshita Y, Yamagiwa J. 2008. Estimating gorilla abundance by dung count in the northern part of Moukalaba-Doudou
National Park, Gabon. Afri. Stud. Mono., 39: 41-54.

Thibault M, Fisher BL, Goodman SM. 2004b. Description of Mounts Doudou, Gabon, and the 2000 biological inventory of the reserve. In Monts Doudou, Gabon: A Floral and Faunal Inventory with Reference to Elevational Distribution, Fisher BL (ed.). California Academy of Science : San Francisco ; 3-16.

Tutin CEG, Ham RM, White LJT, Harrison MJS. 1997. The primate community of the Lope Reserve, Gabon: diets, responses to fruit scarcity, and effects on biomass. Int. J. Prim., 42: 1-24.

Wilson DE, Reeder DM. 2005. Mammal Species of the World. A Taxonomic and Geographic Reference. The Johns Hopkins University Press : Baltimore. 